\title{
The Effect of Advertising Attraction and Brand Embassy on Shopee Purchase Decisions
}

\author{
Farras Nabilah
}

\begin{abstract}
Through the development of technology and the increasing number of internet usage at this time, it is very interesting that many various business businesses to market their products through e-commerce, resulting in considerable business competition for participating companies. In e-commerce business competition, companies use various marketing strategies related to communication, one of which is advertising, because advertising attracts many consumers to see their products on the e-commerce site. In the use of advertising strategies, companies must have a variety of creative concepts in pairing their advertisements, one of which is by requiring ad stars who will present their products to consumers who can be said to be brand ambassadors. Companies must be smart in choosing brand ambassadors who will be used as weapons to market their products in these advertisements, in order to attract many consumers to view these products and buy them. So, the appeal of advertising and brand ambassadors is very important in making purchasing decisions. Because of the existence of attractive advertisements and brand ambassadors that can attract consumers to buy makes the company's best strategy to market its products. The research I did was to analyze the effect of ad appeal on Shopee's online purchasing decisions and also analyze the influence of brand ambassadors on Shopee's online purchasing decisions. The method used in this study is a survey method with a questionnaire as primary data. The results of research that uses the attractiveness of advertising and brand ambassadors find that the attractiveness of advertisements has a significant effect on purchasing decisions and brand ambassadors also show a significant influence on purchasing decisions. So it can be concluded that advertising and brand ambassadors have a very important role in the company's strategy in marketing its products.

Keywords: The attractiveness of advertising, Brand Ambassador and Purchase Decision
\end{abstract}

\section{INTRODUCTION}

In the era of globalization, industry competition is increasingly high in both the domestic (national) and international markets. As a result of this competition, industry people use internet technology by selling online, known as e-commerce. According to Indrajit (2001), e-commerce characteristics consist of transactions between two parties, the exchange of goods, services or information, and the internet as the main media in the transaction process. In addition to the reasons for industry development, the use of internet resources is an impact of the increasing number of potential internet uses in Indonesia from year to year.

Revised Manuscript Received on June 13, 2020.

* Correspondence Author

Farras Nabilah*, Department of Financial And Banking Administration, Perbanas Institute Of Marketing Management, Jakarta, Indonesia. E-mail: farrasnabilah@yahoo.com

(C) The Authors. Published by Blue Eyes Intelligence Engineering and Sciences Publication (BEIESP). This is an open access article under the CC BY-NC-ND license (http://creativecommons.org/licenses/by-nc-nd/4.0/)
Along with the increasing number of internet users in Indonesia, technological developments have shifted customer behavior from purchases through offline shops to purchases through online shops, also known as e-commerce. As of May 018, 40 companies are selling and selling online, one of them is Shopee, Lazada, Blibli, Tokopedia, JDID, and others. One of the companies in Indonesia that applies the concept of e-commerce is PT Shopee Internasional Indonesia, with the Shopee brand. PT Shopee Internasional Indonesia is an international company originating from Singapore and has been followed in Indonesia and other countries namely in Malaysia, Thailand, Vietnam, the Philippines, and Taiwan. Shopee is international e-commerce that first appeared in early 2015 in Singapore as the first mobile marketplace in Southeast Asia. Shopee includes e-commerce that is in great demand to do online purchasing in Indonesia. Shopee in Indonesia has a contribution of 40 percent of all Shopee businesses in 7 countries. As of 2017, as many as 50 million people in 7 countries have downloaded the Shopee application and 18 million of them are from Indonesia while the rest are scattered in Singapore, Malaysia, Thailand, Vietnam, the Philippines, and Taiwan. This can be interpreted that Shopee's campaign to persuade Indonesian people to shop online can be quite successful. The campaigns conducted by Shopee in the last year, such as giving discounts or flash sales, free shipping on certain nominal purchases, 10.10 Big Mobile Purchasing Day, and others are classified as successful. In facing e-commerce competition in Indonesia, Shopee uses several marketing strategies related to communication, one of which is advertising. Advertising is a special form of communication to fulfill the marketing function. To be able to carry out marketing functions, then what must be done in advertising activities, of course, must be more than just providing information to the audience. Advertising must be able to persuade the general public to behave in such a way according to the company's marketing strategy to print sales and profits. Advertising must be able to direct consumers to buy products that the marketing department has designed in such a way that it is believed to meet the needs or desires of the buyer. In short, engagement should be able to influence the selection and buying interest (Jefkins, 1997). Advertising also serves to influence consumers to understand and be aware of the brand that will and has become their choice. Advertising can also be used to build a long-term image and be able to reach potential customers even though it is located far apart, so don't let marketers underestimate the role of advertising, because advertising is an effective way to spread the message or information of a brand to consumers (Istijanto, 2010).

ublished By:

Blue Eyes Intelligence Engineering \& Sciences Publication

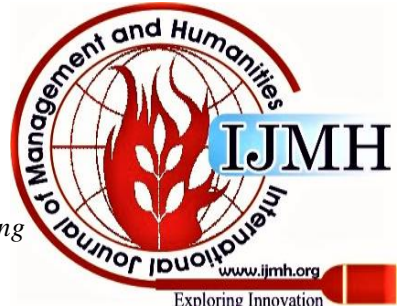




\section{The Effect of Advertising Attraction and Brand Embassy on Shopee Purchase Decisions}

Many media used ways to advertise by Shopee e-commerce, one of them through television media. Shopee must have a creative concept in posting advertisements on television.

Advertising writers and art directors will work together to produce many creative concepts, hoping that one of these concepts will become an interesting big idea. Therefore ad makers must determine the message content, message structure, message format, and the best message source so that the message that will be used to make television advertisements can attract the attention of viewers (Kotler and Susanto, 2001).

Besides, in making Shopee advertisements, Shopee requires ad stars who communicate Shopee is called a brand ambassador or brand ambassador. Rositter and Percy (1997) A brand ambassador is someone who can represent a product or company and can talk a lot about the product being represented so that it has a large impact on product sales. Shopee uses brand ambassadors to emotionally appeal to advertising. The advertisement that presents Prilly Latuconsina as an endorser of the ad, as well as the Brand Ambassador Shopee that is displayed, is enough to attract the attention of viewers to watch it, especially teenagers and students who are starting to switch to the world of buying and selling online. Prilly Latuconsina is a figure that attracts people's attention and can be a factor that influences people's decisions to buy.

Previous research Tampi, et al. (2016) suggested that ad appeal influenced the purchasing decisions of Honda Scoopy motorbikes at PT Daya Adicipta Wisesa. Simarmata's previous research (2016) suggested that the attractiveness variable of advertising influences purchasing decisions. Previous research by Setiawan (2016) suggested that brand ambassadors had a significant effect on greenlight product purchasing decision variables. Previous research Samosir et. al. (2016) suggested that the use of brand ambassadors did not have a major influence on consumer decisions in buying a product.

\section{LITERATURE REVIEW}

\section{A. Buying Decision}

Kotler and Armstrong (2008) suggest that: "Purchasing Decisions are the stages in the buyer decision-making process where consumers buy. Decision making is an individual activity that is directly involved in getting and using the goods offered ".

According to Kotler and Armstrong (2008), there are five stages of the consumer purchasing decision process, namely experience needs, information seeking, alternative evaluations, purchasing decisions and post-purchase behavior. The five stages of the consumer purchasing decision process can be illustrated with the following Purchasing Decision Process images.

\section{Buying Decision Process}

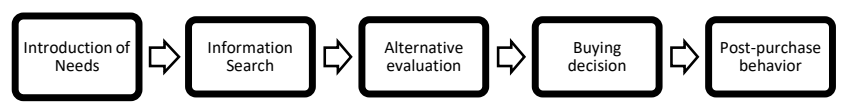

Kotler dan Armstrong (2008)

The consumer purchasing decision process can be explained in more detail as follows:

\section{1) Recognition of Needs (Problem Recognition)}

Recognition of needs occurs when a consumer faces an imbalance between his true state and wants. The recognition of these needs is triggered when consumers are confronted with internal stimuli (thirst, hunger, hope, and dissatisfaction) and external stimuli (design, packaging, product color, advertising on television). The elements of these needs reflect the needs and desires that have not been met. At this stage, the marketer needs to assess to find what types of needs or problems arise or are faced by consumers, what causes them, and how those problems can lead consumers to this particular product (Kotler and Armstorng, 2008).

\section{2) Information Search}

After recognizing their needs and desires, consumers seek information about various alternatives that exist to satisfy their needs. Information search can be internal, namely the process of recalling information stored in memory, and the search for external information, which is the process of finding information in the environment outside the consumer. Consumers can get information from several sources. These sources include personal sources (family, friends, neighbors, associates), commercial sources (advertisements, salespeople, Web systems, distributors, packaging, displays), public sources (mass media, consumer rating organizations, internal search), and sources experience (handling, checking, product usage). Even so, the most effective sources tend to be personal. Commercial sources usually notify buyers, but personal sources legitimize or evaluate products for buyers (Kotler and Armstrong, 2008).

3) Evaluation of Alternatives (Evaluation of Alternative)

Information searches by consumers result in a group of brands sometimes called evoked sets, which are the alternatives most favored by consumers. From this set of considerations, the buyer will then evaluate alternatives and make choices. One way to reduce the number of choices in several considerations is to select an attribute and then exclude all products that do not have that attribute. In the alternative evaluation stage towards the purchase decision, two factors can influence the purchasing decision. The first factor is the attitude of others. The second factor is the situation factor which is not anticipated and changes the purchase intention. In carrying out purchase intentions, consumers can make five purchasing sub-decisions, which include: brand, supplier, quantity, time and payment methods. Accordingly, marketers must study buyers to find out how they evaluate brand choices. If consumers know what evaluation processes are taking place, marketers can take steps to influence purchasing decisions (Kotler and Armstorng, 2008).

\section{4) Purchase Decision}

In the evaluation phase, consumers determine brand rankings and form purchase intentions. In general, a consumer's purchasing decision is to buy the most preferred brand, but two factors can exist between purchasing research and purchasing decisions. The first factor is the attitude of others. The second factor is unexpected situational factors.

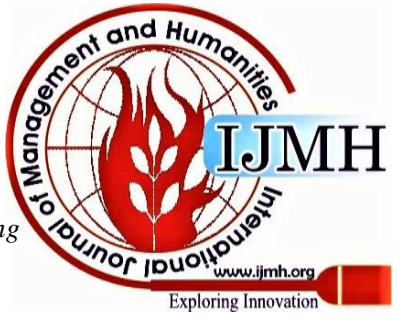


Consumers may form purchase intentions based on factors such as income, price, and expected product benefits. However, unexpected events can also change purchase intentions, whether caused by consumers themselves or by company salespeople (Kotler and Armstrong, 2008).

5) Post Purchase Behavior

When purchasing a product, consumers expect a certain impact on the purchase. Purchasing of a product provides three possible outcomes received by consumers, namely:

a. If the purchase results are as expected, then the consumer will feel quite satisfied

b. If the purchase results exceed expectations, consumers will feel satisfied

c. If the purchase results are below expectations, then the consumer will experience disappointment or dissatisfaction.

At this stage, the next consumer action after purchase, based on customer satisfaction or dissatisfaction. The marketer's job does not end when the product has been purchased. After buying a product, consumers will feel satisfied or dissatisfied and engage in post-purchase behavior that must be considered by marketers. What determines the satisfaction or dissatisfaction of purchase lies in the relationship between consumer expectations and the perceived performance of the product. If the product does not meet expectations, consumers are disappointed. If the product meets expectations, the consumer is satisfied. If the product exceeds expectations, the consumer is very satisfied. The greater the gap between expectations and performance, the greater the consumer dissatisfaction. This shows that the seller can only promise what the brand can give so that the buyer is satisfied (Kotler and Armstrong, 2008).

\section{B. Attraction of Advertising}

The appeal of power or the power of impression of an ad is how much the advertisement can amaze or attract the attention of its viewers (Indiarto, 2006). The attractiveness of advertising is a trait owned by someone who can cause a sense of interest in himself (Sukmawati and Suyono, 2005). It can be concluded that the appeal of advertising is the ability of advertisements to attract the attention of viewers.

One of the factors that influence the success of advertising messages is the attractiveness of advertisements, as stated by Kotler \& Armstrong (2008) which states that the communicator in composing advertising messages must think about what will be said, must find the attraction that will produce the desired response. The attractiveness of advertising is very important because it will increase the success of communication with the audience (Sutisna, 2003).

An attractive ad is an ad that has an appeal, which can attract the attention of the target market (audience). The messages to be conveyed can be presented in different delivery styles, namely by displaying: footage of individual or group lives, individual lifestyles, fantasies about the product, moods or images around the product, music to bring more messages, symbols personality to create characters that personify products, showcase the expertise and experience of companies in producing products, scientific evidence of product superiority, evidence or testimony from famous people (Tjiptono, 2008). The attractiveness of advertising can be measured by using several variables. According to Shimp (2003), the attractions that are often used in advertising include:

1) The appeal of the supporting role (the endorser) in advertising

Many advertisements have explicit endorsements from various popular figures. Besides, to support from celebrities, the products also receive explicit support from celebrities. According to the order of importance, the first consideration is endorser credibility, endorser compatibility with the audience, endorser match with the brand, endorser appeal, and then other considerations.

2) The attractiveness of humor in advertising

The use of humor is very effective in getting people to pay attention to advertising and create brand awareness. When done correctly and in the right circumstances, humor can be a very effective method of modeling. In-depth research results from the humor director produced several tentative conclusions, namely:

a. Humor is an effective method for attracting attention

b. Humor adds fun to the advertisements and brands that are advertised

c. Humor does not damage the understanding of the product

d. Humor does not offer an advantage that is more than just persuasion

e. Humor does not add source credibility

f. The nature of the product influences the use of humor. In particular, humor will be more successful when used on established products than on new products. Humor is also more for products that are more oriented to feelings, or experience, and to products that do not need consumer involvement.

\section{3) The attraction of fear}

The use of fear is expected to be very effective as a way to increase motivation. Advertisers try to motivate customers to process information and take action by using a fear appeal that mentions the negative consequences of not using the product being advertised, or the negative consequences of bad behavior. The logic that underlies the use of the attraction of fear is to engage the audience with messages to encourage the acceptance of message arguments.

\section{4) Guilt as a teaser}

Like fear, guilt also lures negative emotions. The attraction to guilt is strong because emotionally guilty motivates adults to take responsible action that causes a decrease in the guilt level. Advertisers and other marketing communicators present guilt and try to persuade potential customers by asserting or concluding that guilt can be removed by using the product that is being promoted.

5) The use of sexual elements in advertising

Ads that contain sexual attraction will be effective if this is relevant to the sales message in the ad. However, when used large, it can cause attention, improve memory and create pleasant associations with advertised products.

\section{6) The attractiveness of advertising music}

Music has been an important component of the advertising world almost since sound was first recorded. Jingle, background music, popular tunes, and classical arrangements are used to attract attention, channel sales messages, determine emotional pressure for advertisements, and influence the mood of listeners.

Researchers do not use these indicators because some indicators are not in Shopee advertisements, such as the appeal of humor, guilt, and the use of sexual elements.

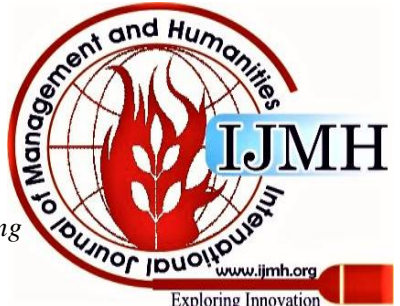


The attractiveness of advertising must have 3 (three) characteristics, meaningful, distinctive, and believable. First, the ad must be meaningful, showing the benefits that make the product more desirable or more attractive to consumers.

Second, advertising messages must be believable, consumers believe that the product will provide benefits as promised in the advertising message. Third distinctive, those advertising messages are better than competing brand ads (Kotler \& Armstrong, 2008). This study uses indicators meaningful (distinctive), distinctive (better than competitors), and believable (trustworthy) to measure the attractiveness of advertising variables. These three indicators can cover the overall variable attractiveness of advertising.

\section{Brand Ambassadors}

All According to Soehadi (2005), brand ambassadors can be described as someone who presents the best portrait of a product or service. This person could be a company operators, customer or celebrity endorser. All representatives, regardless of position, are key ambassadors for the company's products/services. the internal branding process is a determining factor in creating brand ambassadors.

Shimp (2003) says that brand ambassadors are advertisement supporters or also packaged as advertising stars that support advertised products. The brand ambassadors are expected to be the spokesperson of the brand so that it quickly attaches to the minds of consumers, so consumers want to buy the brand. Besides, celebrities can also be used as an appropriate tool to represent targeted market segments. In addition to being well-known, credible, trustworthy and attractive, someone chosen as a brand ambassador must be someone who is admired and respected and matches the target market. Therefore it is not surprising that the products being advertised use a lot of celebrities, each of which will represent a targeted market segment (Royan, 2004).

From the above notions expressed by some experts, it can be concluded that brand ambassadors or brand ambassadors are individuals or groups who have popularity, expertise, attractiveness, and strength in conveying a message or representing a product or service in inviting consumers.

To become a brand ambassador who can benefit the advertised product, several important factors need to be considered. Brand ambassadors should be selected to match personal characteristics with the communication effects that they want to emerge or appear in the campaign. The model that can be used to derive the characteristics of brand ambassadors with objective communication is the VisCAP model. According to Rossiter and Percy (1997), the VisCAP model is used to evaluate potential vendors based on audience perceptions of the endorser:

\section{Visibility}

Characteristics of visibility of a brand ambassador lead to how famous or known from the general public. Ideally, attention to well-known brand ambassadors will be devoted to the brand. High visibility will produce greater attention.

\section{Credibility}

As the credibility of the brand ambassador includes expertise and trust. Credibility is a set of communicant perceptions about the nature of the communicator. Credibility refers to the extent to which audiences view endorsers as someone who has relevant knowledge, abilities, or experience and trusts endorsers to provide objective information (Belch \& Belch, 2001).

a. Expertise refers to the breadth of endorser's knowledge seen by ad audiences. Expertise is very relevant to use when advertising is based on an informational brand attitude strategy, both low involvement product or high involvement product

b. Objectivity refers to the breadth of endorsers seen to convey information in unusual and objective ways. Objectivity is very relevant to be used for informational brand attitude strategy, especially in product improvement because the arguments presented in advertisements must be convincing. Many celebrities have honest and sincere reputations. However, objectivity can be found in non-celebrity endorsers.

\section{Attraction}

The attraction includes physical attractiveness, as well as a set of values such as intellectual abilities, personal property, lifestyle characteristics, and athletic abilities, which can be accepted by the audience from a source (Shimp, 2003).

a. Likeability, the most relevant is used in low involvement products, where products like this need a stimulus that can create positive motivation for the brand. If the level of public preference for endorsers is higher, then advertising will be more persuasive.

b. Similarity refers to the similarity of the endorser to the target user. The audience must identify the emotional picture in the ad, which is convinced by showing people who have a lifestyle similar to the target user. Therefore, this similarity is most relevant for high involvement products.

\section{Strength (Power)}

Power can increase the desire to buy a product, by displaying "orders" to the audience to act. But this is only relevant in a few situations. Power is very relevant to be used for products that use fear appeals, such as medical products, insurance, financial services, and public security campaigns.

\section{CONCEPTUAL FRAMEWORK}

From the explanation above, the framework used in this study is as follows:

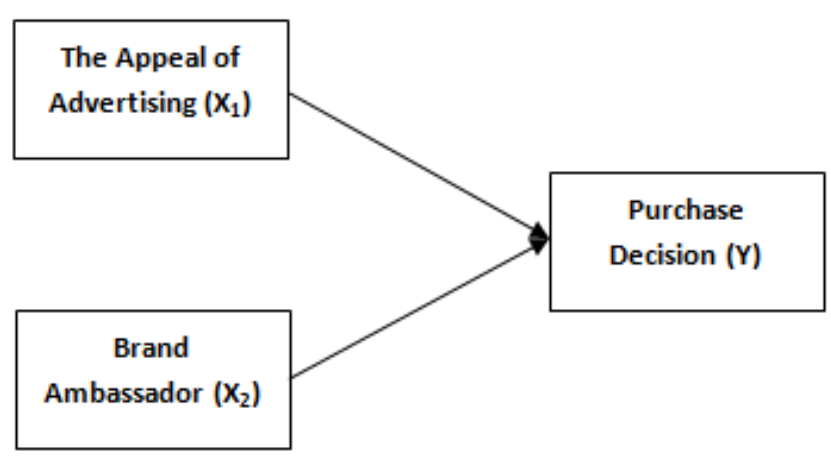

Information:

H01: The appeal of advertising has no significant effect on Shopee's online purchasing decisions

Ha1: The attractiveness of advertising has a significant influence on Shopee's online purchasing decisions

H02: Brand ambassadors have no significant effect on Shopee's online decisions

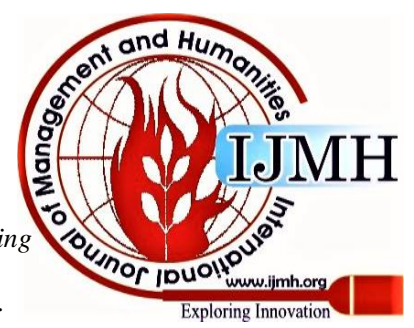


Ha2: Brand ambassadors have a significant influence on Shopee's online purchasing decisions.

\section{RESEARCH METHODS}

This The method used in this study is a quantitative method with descriptive research methods, namely activities that include collecting data to test hypotheses or answer questions regarding the situation at the time that is running from the subject of a study. The method in this study was used to determine the effect of the attractiveness of advertising and brand ambassadors on purchasing decisions. The research study unit consists of research subjects and objects. The subject of this research is Shopee.co.id, while the object of this research is consumers in the DKI Jakarta area who have been purchasing through Shopee's purchasing service. So researchers took the total sample for research is 100 samples. The sample in this study is consumers who have seen Shopee ads and have made purchases through Shopee's online purchasing services. After the questionnaire is distributed to respondents, then the data quality test is carried out. The results of the validity test of the purchase decision variable.

Table 1

\begin{tabular}{|c|c|c|c|}
\hline \multicolumn{4}{|c|}{ Table Validity } \\
\hline No. & Score $\mathrm{r}$ & $\begin{array}{l}\text { Score } \\
\text { Table }\end{array}$ & Explanation \\
\hline 1 & 0.789 & 0.361 & Valid \\
\hline 2 & 0.832 & 0.361 & Valid \\
\hline 3 & 0.836 & 0.361 & Valid \\
\hline 4 & 0.727 & 0.361 & Valid \\
\hline 5 & 0.762 & 0.361 & Valid \\
\hline 6 & 0.861 & 0.361 & Valid \\
\hline 7 & 0.771 & 0.361 & Valid \\
\hline 8 & 0.637 & 0.361 & Valid \\
\hline 9 & 0.823 & 0.361 & Valid \\
\hline 10 & 0.744 & 0.361 & Valid \\
\hline 11 & 0.712 & 0.361 & Valid \\
\hline 12 & 0.717 & 0.361 & Valid \\
\hline 13 & 0.693 & 0.361 & Valid \\
\hline 14 & 0.886 & 0.361 & Valid \\
\hline 15 & 0.775 & 0.361 & Valid \\
\hline
\end{tabular}

Reliability Statistics

\begin{tabular}{r|r|} 
Cronbach's Alpha & N of Items \\
\hline
\end{tabular}

$$
.946
$$

\section{Source : SPSS, 2018}

Table 1 above, all statements on the purchase decision variable indicator have a validity value greater than the $\mathrm{r}$ table that is 0.361 , thus, all statements on the purchase decision variable indicator are declared valid. While the reliability value, the alpha value is higher than $60 \%$ or 0.6 , namely 0.946 , so that all statements can be stated on the variable indicators of a reliable purchase decision.

Table 2

\begin{tabular}{|c|c|c|c|}
\hline \multicolumn{5}{|c|}{ Table Validity } \\
\hline No & Score $\mathrm{S}$ & $\begin{array}{l}\text { Score } \\
\text { Table }\end{array}$ & Explanation \\
\hline 1 & 0.691 & 0.361 & Valid \\
\hline 2 & 0.782 & 0.361 & Valid \\
\hline 3 & 0.761 & 0.361 & Valid \\
\hline 4 & 0.673 & 0.361 & Valid \\
\hline
\end{tabular}

\begin{tabular}{|l|l|l|l|}
\hline 5 & 0.692 & 0.361 & Valid \\
\hline 6 & 0.761 & 0.361 & Valid \\
\hline 7 & 0.883 & 0.361 & Valid \\
\hline 8 & 0.791 & 0.361 & Valid \\
\hline 9 & 0.828 & 0.361 & Valid \\
\hline
\end{tabular}

\section{Reliability Statistics}

\begin{tabular}{|l|l|} 
Cronbach's Alpha $\quad$ N of Items \\
\hline
\end{tabular}

$$
.907
$$

Source : SPSS, 2018

Table 2 above, all statements on the indicator of attractiveness advertising variables have a validity value greater than $r$ table that is 0.361 , thus, all statements on the indicator of attractiveness advertising variables are declared valid. While on the reliability value, the alpha value is higher than $60 \%$ or 0.6 , that is 0.907 , so that all statements can be stated on the variable attractiveness of reliable advertising indicators.

Table 3

Table Validity

\begin{tabular}{|c|c|c|c|}
\hline \multicolumn{5}{|c|}{ Table Validity } \\
\hline No. & Score $\mathrm{r}$ & $\begin{array}{l}\text { Score } \\
\text { Table }\end{array}$ & Explanation \\
\hline 1 & 0.826 & 0.361 & Valid \\
\hline 2 & 0.794 & 0.361 & Valid \\
\hline 3 & 0.715 & 0.361 & Valid \\
\hline 4 & 0.739 & 0.361 & Valid \\
\hline 5 & 0.767 & 0.361 & Valid \\
\hline 6 & 0.890 & 0.361 & Valid \\
\hline 7 & 0.890 & 0.361 & Valid \\
\hline 8 & 0.826 & 0.361 & Valid \\
\hline 9 & 0.806 & 0.361 & Valid \\
\hline 10 & 0.880 & 0.361 & Valid \\
\hline
\end{tabular}

\section{Reliability Statistics}

\begin{tabular}{|l|l|} 
Cronbach's Alpha & N of Items \\
\hline
\end{tabular}

.939

Table 3 above, all statements on the brand ambassador variable indicator have a validity value greater than $r$ table that is 0.361 , thus, all statements on the brand ambassador variable indicator are declared valid. While the reliability value, the alpha value is higher than $60 \%$ or 0.6 which is 0.939 , so that all statements can be stated on the variable indicators of reliable brand ambassadors.

\section{RESULTS AND DISCUSSION}

Table 4

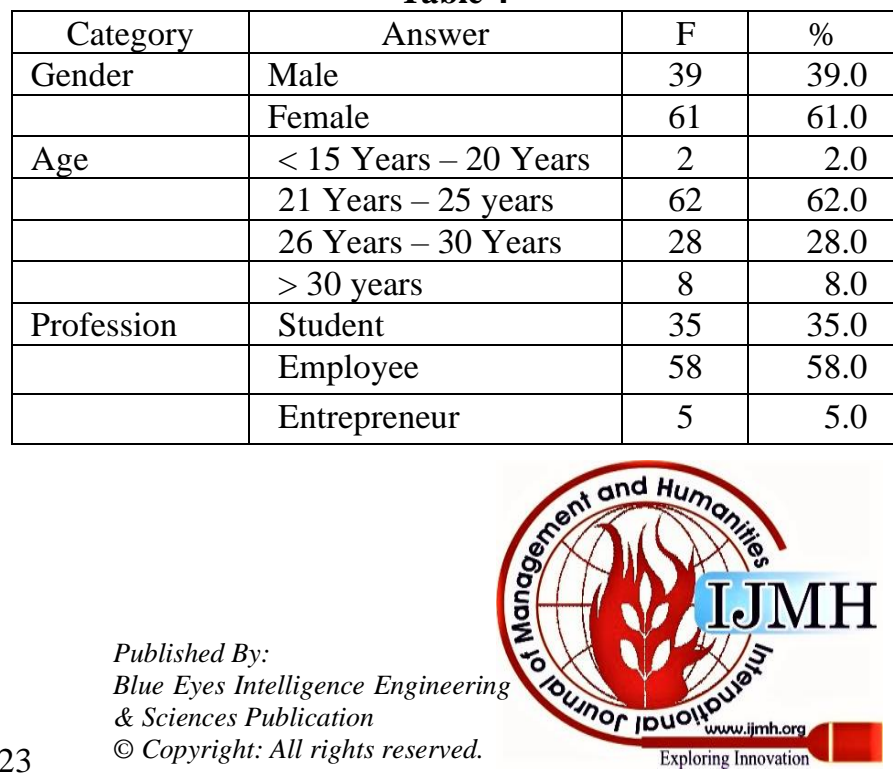


The Effect of Advertising Attraction and Brand Embassy on Shopee Purchase Decisions

\begin{tabular}{|l|l|c|r|}
\hline & Etc & 2 & 2.0 \\
\hline $\begin{array}{l}\text { Spending } \\
\text { money per } \\
\text { month }\end{array}$ & $\begin{array}{l}<\text { Rp. } 500.000-\text { Rp. } \\
2.000 .000\end{array}$ & 28 & 28.0 \\
\hline & $\begin{array}{l}\text { Rp. } 2.000 .000-\text { Rp. } \\
5.000 .000\end{array}$ & 38 & 38.0 \\
\hline & $\begin{array}{l}\text { Rp. } 5.000 .000-\text { Rp. } \\
10.000 .000\end{array}$ & 30 & 30.0 \\
\hline & $>$ Rp. 10.000 .000 & 4 & 4.0 \\
\hline
\end{tabular}

It can be concluded that the majority of respondents are women aged 21 years -25 years an employee / civil servant/military/police and have a monthly expenditure of Rp. 2,000,000 - Rp. 5,000,000.

Source : SPSS, 2018

Table 5

Recapitulation of Research Results Purchase Decision Variables (Y)

\begin{tabular}{|l|l|}
\hline Statement & Score \\
\hline 1. Shopee sells a variety of products that I need & 437 \\
\hline 2. I understand that the conditions of products sold can be different from expectations & 405 \\
\hline 3. I buy products at Shopee if I really need it & 396 \\
\hline 4. I feel the information provided about the products at Shopee can be trusted & 380 \\
\hline 5. I prefer to look for information provided by other consumers in the review column & 394 \\
\hline 6. I believe more in the information provided from the experiences of other consumers & 430 \\
\hline 7. I always evaluate in advance between products sold offline and those sold online & 448 \\
\hline 8. I feel the information provided about the products at Shopee can be trusted & 418 \\
\hline 9. I will select various prices for the same product at Shopee & 412 \\
\hline 10. I made a purchase after feeling that I had gotten enough information & 387 \\
\hline 11. I decided to make a purchase based on the positive experiences of other consumers & 393 \\
\hline 12. I buy products based on the choices that I think are the most profitable & 328 \\
\hline 13. I feel satisfied buying products at Shopee & 380 \\
\hline 14. I will give recommendations to others because they are satisfied & 432 \\
\hline 15. I will make a repeat purchase at Shopee & 391 \\
\hline Total Average & 402.04 \\
\hline
\end{tabular}

Source : SPSS, 2018

The statement with the lowest score is in statements number 4 and 13, which is that I feel the information provided about the products at Shopee is trustworthy and I feel satisfied that I have purchased the product at Shopee. While the statement that has the highest score is found in statement number 7, which is that I always evaluate first the products sold offline and those sold online. Next, we can see the Recapitulation of the Results of the Attractiveness Research Variable (X1) below:

Table 6

Recapitulation of Research Results Variable Attractiveness Advertising $\left(\mathbf{X}_{1}\right)$

\begin{tabular}{|l|l|}
\hline Statement & Score \\
\hline 1. The message that Shopee shows explains what is wanted & 439 \\
\hline 2. The message that Shopee showed caught my attention & 446 \\
\hline 3. The message contained in Shopee ads is as is & 372 \\
\hline 4. Celebrities have good popularity & 379 \\
\hline 5. Celebritis has an attractive physique & 404 \\
\hline 6. Celebrities have good credibility & 402 \\
\hline 7. The ad that aired convinced me & 411 \\
\hline $\begin{array}{l}\text { 8. Shopee ads contain good content / information that is different from other online shopping } \\
\text { advertisements }\end{array}$ & 379 \\
\hline 9. The ads that are displayed contain special benefits & 426 \\
\hline Total Average & 406.43 \\
\hline
\end{tabular}

Source : SPSS, 2018

The statement with the lowest score is found in statement number 3, which is the message contained in the Shopee ad as it is. While the statement that has the highest score is found in statement number 2, the message that Shopee is broadcasting attracts my attention. Next, we can see the Summary of Research Results of the Brand Ambassador Variables (X2) below: 
Table 7

Summary of Research Results of Brand Ambassadors Variables $\left(\mathrm{X}_{2}\right)$

\begin{tabular}{|l|l|}
\hline Statement & Score \\
\hline 1. Prilly Latuconsina's popularity is very good & 446 \\
\hline 2. The charm that Prilly Latuconsina has is very good & 432 \\
\hline 3. The suitability of Prilly Latuconsina as a brand ambassador & 398 \\
\hline 4. Trust in the figure of Prilly Latuconsina as the brand ambassador & 378 \\
\hline 5. Prilly Latuconsina's self-image is good & 430 \\
\hline 6. The charm of Prilly Latuconsina which is owned well & 432 \\
\hline 7. The suitability of Prilly Latuconsina became a popular model & 427 \\
\hline 8. Prilly Latuconsina's achievements are good & 382 \\
\hline 9. I feel that Prilly Latuconsina increases the intensity of purchases of goods & 384 \\
\hline 10. Proximity of Prilly Latuconsina to the desires of consumers & 438 \\
\hline Total Average & 413.47 \\
\hline
\end{tabular}

Source : SPSS, 2018

The statement with the lowest score is in statement number 4, namely Trust in the character Prilly Latuconsina as the brand ambassador. While the statement that has the highest score is found in statement number 1, namely the popularity of Prilly Latuconsina is very good.

Hypothesis test results can be seen in table 8. The attractiveness of advertising has a significant effect on Shopee's online purchasing decisions. This is evidenced by the results of the SPSS calculation which states that the $t$ count of the ad appeal variable is greater than the table and the Sig. The variable attractiveness of advertisements is smaller than 0.05 . This variable is said to be influential

Table 8

Partial Testing

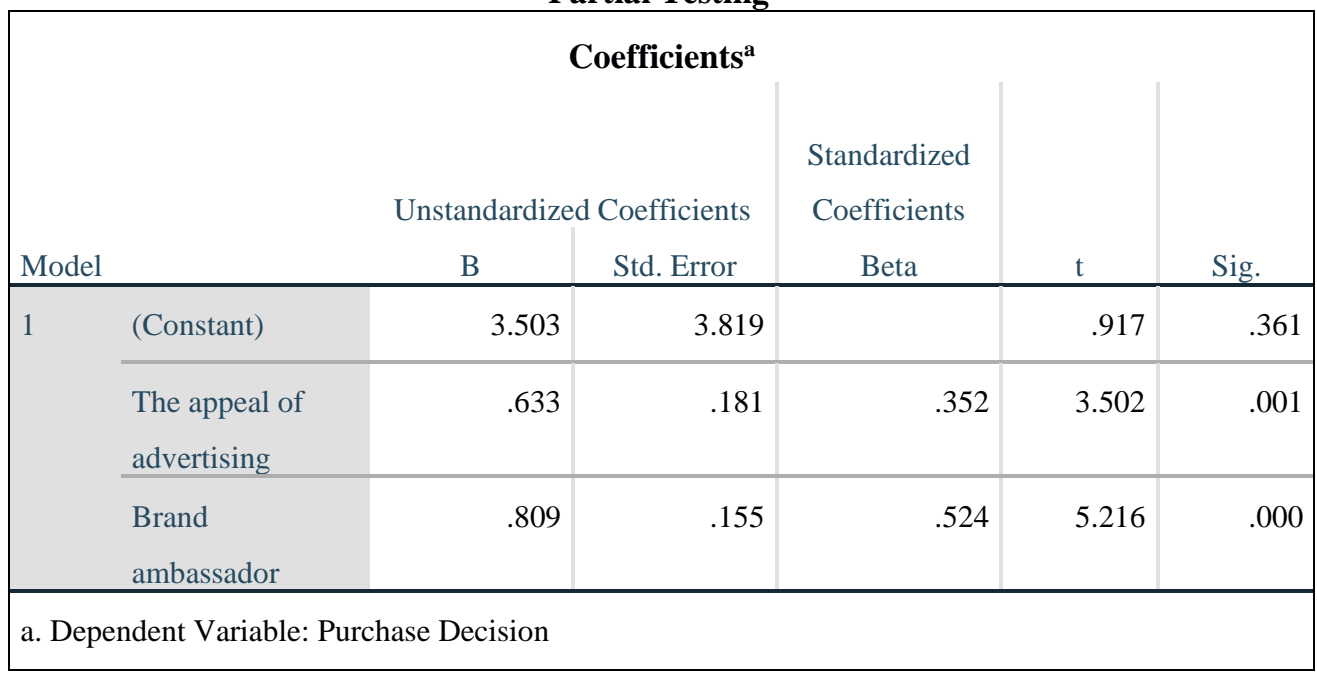

Source : SPSS, 2018

Based on the results of the regression, the attractiveness of advertising influences the purchase decision. Also, brand ambassadors influence purchasing decisions. Thus, the two hypotheses proposed in this study can be accepted.

For hypothesis 1 this study is by the results of research conducted by Nugraha (2018) which states that there is a significant influence of advertising attractiveness on purchasing decisions and also the results of research conducted by Tampi, Soegoto and Sumarauw (2016) which states that the attractiveness of advertising influences on purchasing decisions as well as the results of research by Simarmata (2016) which says that the attractiveness of advertising variables influence the purchase decision.

For hypothesis 2, this research is by the results of research conducted by Setiawan (2016) which states that brand because of the value of $\mathrm{t}$ arithmetic and Sig. the positive. Thus, Ha1 is not rejected and Ho1 is rejected. Then for brand ambassador variables, significant influence on Shopee's online purchasing decisions. This is evidenced by the results of the SPSS calculation which states that the t count of the ad appeal variable is greater than the table and the Sig. The brand ambassador variable is smaller than 0.05 . This variable is said to be influential because of the value of $t$ arithmetic and Sig. the positive. Thus, Ha2 is not rejected and Ho2 is rejected. ambassadors have a significant effect on purchasing decision variables but are inversely proportional to the results of research conducted by Samosir, Putri and Nurfebiaraning (2016) which says that the use of brand ambassadors does not have a major influence on consumer decisions in buying a product.

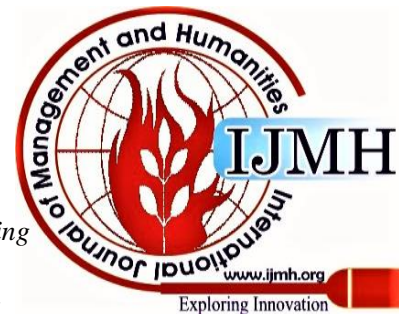




\section{CONCLUSION}

Based on the results of research and hypothesis testing in this study, it can be concluded as follows:

1) Significant advertising appeal to Shopee's bold buying decisions. This is evidenced by the results of the SPSS calculation which states that $t$ calculate the variable attractiveness of advertisements greater than t table and Sig. Ad attractiveness variable is smaller than 0.05 . This variable approves, because the value of $t$ is calculated and the value of Sig. the positive. Thus, Ha1 is not rejected and Ho1 is rejected. The results of this study are consistent with the results of research conducted by Nugraha (2018) which states that there is a significant influence on advertising on purchases and also the results of research conducted by Tampi, Soegoto and Sumarauw (2016) related to this study. purchase and the results of research by Simarmata (2016) which says that the attractiveness variable of advertising concerns purchasing decisions.

2) Ambassadors apply significantly to Shopee's bold purchasing decisions. This is evidenced by the results of the SPSS calculation which states that $t$ calculate the brand ambassador variable is greater than t table and Sig. The brand ambassador variable is smaller than 0.05 . This variable approves, because the value of $t$ is calculated and the value of Sig. the positive. Thus, Ha2 is not rejected and Ho2 is rejected. The results of this study are consistent with the results of research conducted by Setiawan (2016) which states that brand ambassadors have a significant effect on purchase outcome variables but are inversely proportional to the results of research conducted by Samosir, Putri and Nurfebiaraning (2016) who say they want to use brand ambassadors do not play a big role in consumer decisions in buying a product.

\section{IMPLICATION}

The implication of this research is on the dimension of the attractiveness of advertisements at point number 4 , which is the message contained in Shopee, getting the lowest results than the others. And expanding more diverse types of discounts to be able to be enjoyed by all customers.

\section{RESEARCH LIMITATIONS}

Limitations of researchers in this study are:

1) The data collection method uses a questionnaire, so the data may be subjective, it would be better if the interview method was added so that the research results obtained were more complete.

2) This study only examined the attractiveness of advertisements and brand ambassadors that influenced purchasing decisions. Thus, it is necessary to explore other variables that can influence purchasing decisions, such as brand image, trust, convenience (ease of use), e-WOM (electronic word of mouth).

\section{SUGGESTION}

1) To improve purchasing decisions so that the company is higher than before it is expected to be able to further explore the attractiveness of advertising and brand ambassadors in its ad impressions. This deepening can provide more information to consumers about matters that are procedural, such as ordering steps and transaction security.

2) Considering there are still many variables outside the study that influence purchasing decisions by $21.9 \%$, the next researcher is expected to develop research by examining other variables that are outside this study or combining the variables contained in this study with other variables.

\section{REFERENCES}

1. A, Shimp,Terence 2003. Periklanan Promosi\&Aspek Tambahan Komunikasi Pemasaran.Terpadu, Jilid I ( edisi 5), Jakarta: Erlangga.

2. Agus W., Soehadi. 2005. Effective Branding. Bandung: PT. Mizan Pustaka

3. Belch, George E., Michael A. Belch. 2001. Advertising and Promotion: An. Integrated Marketing Communication Perspective. Fourth Edition. Boston: McGraw Hill

4. Frank Jefkins, 1997. Periklanan,Jakarta: Erlangga. Hlm 15

5. Indrajit, 2001, Analisis dan Perancangan Sistem Berorientasi Object. Bandung, Informatika.

6. Morrisan, M.A, 2010. Periklanan: Komunikasi Pemasaran Terpadu, Jakarta: Kencana Prenada Media Group. Hlm 17

7. Phillip Kotler dan A.B. Susanto. 2001. Manajemen Pemasaran, Buku 2.PT. SalembaEmpat Patria. Jakarta. Hlm 154-160

8. Philip Kotler, Armstrong, Garry, 2008. Prinsip-prinsip Pemasaran, Jilid1, Erlangga, Jakarta.

9. Rossiter, John. R And Larry Percy.1997.Advertising And Promotion Management. Mc-Graw-Hill Inc. lright All Reserved Printed In The United States Of America

10. S.Bekti Istiyanto,S.Sos (Dosen Ilmu Komunikasi Fisip Unsoed). 2010 Wanita dalam Gambaran Iklan Televisi Kita.Hlm 1.

11. Sugioyono. 2011. Metode Penelitian Kuantitatif, Kualitatif dan R\&D. Bandung:Alfabeta.

12. Sugiyono. 2008. Metode Penelitian Bisnis. Bandung: CV. Alfabeta

13. Sutisna, 2003. Perilaku Konsumen dan Komunikasi Pemasaran, Cetakan Ketiga. Bandung: PT. Remaja Rosdakarya.

14. www.apjii.or.id

15. https://technologue.id/lewati-lazada-dan-tokopedia-e-commerce-ini-jad i-yang-terpopuler-di-indonesia/amp/

16. https://ekonomi.kompas.com/read/2017/09/27/192814226/indonesia-ja di-pasar-terbesar-shopee

\section{AUTHORS PROFILE}

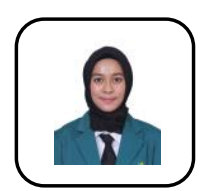

Farras Nabilah, author nickname is Bella, The author lives in Jakarta, Indonesia. Born in Jakarta, December 30, 1995. The author graduated diploma from an Indonesian university majoring in financial and banking administration in 2013 and in 2018 graduated bachelor from Perbanas Institute of marketing management. During lectures, The author participated in a number of organizations, such as student department associations and community empowerment organizations through Financial Planning Education, Investment for Micro small and medium enterprises. The author has had the opportunity to present at the 2015 ASEAN Leadership Conference Conference "Become a part of Global Netizens" in 2015. The author currently works for PT Pamerindo Indonesia. The author can be contacted at the email address: farrasnabilah@yahoo.com

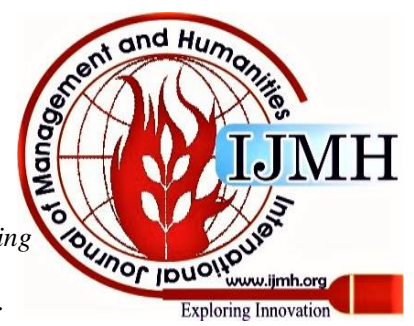

